\title{
ANALISIS PERKEMBANGAN SISWA USIA DASAR PADA RELASI TEMAN SEBAYA
}

\author{
Azmah Marvavilha \\ Magister PGMI UIN Sunan Kalijaga Yogyakarta \\ Email: nabilvilha@gmail.com
}

\begin{abstract}
Abstrak
Fenomena penyimpangan atau kenakalan remaja dan anak yang saat ini mulai mendapat perhatian secara serius oleh masyarakat. Pada umumnya jenis kenakalan itu tergolong pada tiga hal utama, yaitu : 1) penyalah gunaan narkoba, 2) seks bebas dan 3) tawuran antar remaja. Potret ini menunjukan bahwa kita saat ini sedang diuji untuk memecahkan beberapa persoalan yang sedang dihadapi oleh anak, sehingga orang tua dan guru harus melakukan kerja ekstra agar kedepan pertumbuhan dan perkembangan anak bisa berjalan sebagaimana mestinya. Pada anak usia sekolah dasar, berteman serta bersosialisasi dengan teman sebaya memberikan kontribusi bagi anak untuk bisa memahami dirinya dan juga memahami orang lain. Menjalin relasi atau hubungan dengan teman sebaya, merupakan salah satu contoh dari perkembangan sosial yang dimiliki oleh anak-anak pada usia sekolah dasar. Pada anak usia sekolah dasar, relasi atau menjalin hubungan dengan teman sebaya menjadi hal penting dalam perkembangan anak usia sekolah dasar. Penerimaan sosial berarti ia dipilih sebagai teman untuk suatu aktivitas dalam kelompok di mana seseorang menjadi anggota. Ini merupakan indeks keberhasilan bagi seorang anak yang digunakan untuk berperan dalam suatu kelompok sosial dan menunjukkan derajat rasa suka anggota kelompok yang lain untuk dapat bekerja atau bermain dengannya.
\end{abstract}

Kata Kunci: Perkembangan, Usia Dasar, Teman Sebaya

\section{PENDAHULUAN}

7 - Deman sebaya atau peers adalah anak-anak dengan tingkat kematangan atau usia yang kurang lebih sama. Salah satu fungsi terpenting dari kelompok teman sebaya adalah untuk memberikan sumber informasi dan komparasi tentang dunia di luar keluarga. Teman sebaya sendiri memiliki arti yaitu sejauh mana individu mampu diterima secara sosial oleh kelompok penerima teman sebayanya (Bricker, 2000). Melalui kelompok teman sebaya anak-anak menerima umpan balik dari teman-teman mereka tentang kemampuan mereka. Anak-anak menilai apa-apa yang mereka lakukan, apakah dia lebih baik dari pada teman-temannya, sama, ataukah lebih buruk dari apa yang 
anak-anak lain kerjakan. Hal demikian akan sulit dilakukan dalam keluarga karena saudara-saudara kandung biasanya lebih tua atau lebih muda (bukan sebaya). Hubungan yang baik di antara teman sebaya akan sangat membantu perkembangan aspek sosial anak secara normal. Anak pendiam yang ditolak oleh teman sebayanya, dan merasa kesepian berisiko menderita depresi. Anak-anak yang agresif terhadap teman sebaya berisiko pada berkembangnya sejumlah masalah seperti kenakalan dan drop out dari sekolah.

Gladding mengungkapkan bahwa dalam interaksi teman sebaya memungkinkan terjadinya proses identifikasi, kerjasama dan proses kolaborasi. Proses-proses tersebut akan mewarnai proses pembentukan tingkah laku yang khas pada remaja. Penerimaan tersebut biasanya dapat terjadi berdasarkan pengakuan akan kesamaan dari kelompok penerimaan teman sebaya (Cook dan Sammel, 1999).

Selain dari beberapa persoalan penting yang sedang dihadapai oleh anak sebagaimana yang disampaikan oleh penulis diatas. Saat ini kita juga sedang dihadapi oleh fenomena penyimpangan atau kenakalan remaja dan anak yang saat ini mulai mendapat perhatian secara serius oleh masyarakat. Pada umumnya jenis kenakalan itu tergolong pada tiga hal utama, yaitu : 1) penyalah gunaan narkoba, 2) seks bebas dan 3) tawuran antar remaja. Potret ini menunjukan bahwa kita saat ini sedang diuji untuk memecahkan beberapa persoalan yang sedang dihadapi oleh anak, sehingga orang tua dan guru harus melakukan kerja ekstra agar kedepan pertumbuhan dan perkembangan anak bisa berjalan sebagaimana mestinya.

Mengajarkan pada anak-anak usia sekolah dasar dan sederajat (MI) menjadi sangat strategis karena mereka adalah anak yang tumbuh dengan pesat secara biologis maupun psikis. Mereka suka meniru tanpa berupaya untuk mengkritisinya terlebih dahulu. Oleh karena itu Dalam tulisan ini penulis akan mendiskripsikan pembehasan tentang analisis perkembangan siswa usia dasar pada teman sebaya.

TINJAUAN TEORITIS

Perkembangan Siswa Usia Dasar Pada Teman Sebaya 
Teman bagi seorang anak akan selalu datang dan pergi, hal tersebut berlaku untuk kawan, teman, dan sahabat. Terdapat beberapa sebab yang bisa memunculkan adanya pergantian teman pada anak usia sekolah dasar, diantaranya adalah (Elizabeth B. Hurlock, 1978):

1. Perubahan minat. Apabila minat dalam bermain, tugas sekolah atau topik pembicaraan berubah, maka anak akan beralih ke teman yang memiliki minat yang sama dengan mereka.

2. Perubahan nilai. Dengan berubahnya minat dan matangnya perilaku, maka anak akan mempertimbangkan makna penting berbagai kegiatan bermain atau cara berperilaku dalam situasi sosial. Kemudian mereka akan memilih teman yang memiliki kesamaan nilai dengan mereka.

3. Perilaku antisosial. Anak yang perilakunya antisosial pada saat teman seusianya mulai menampilkan perilaku yang lebih sosial akan melihat bahwa bekas teman dan sahabatnya beralih ke teman yang memiliki perilaku lebih sosial dibandingkan dengan perilakunya.

4. Kurangnya wawasan sosial. Anak yang wawasan sosialnya kurang berkembang dibandingkan dengan yang memiliki wawasan sosial maka akan dianggap kurang bijaksana. Bila mereka tidak memperlihatkan rasa simpati terhaap teman mereka, kemungkinan besar mereka akan mengalami penolakan.

5. Tekanan dari orang lain. Tekanan dari orang lain, misalnya orang tua dan temannya untuk senantiasa berteman karena berdasarkan jenis kelamin, ras, ekonomi, akan menyebabkan anak akan memutuskan hubungan dengan teman lamanya dan menjalin pertemanan dengan teman yang disetujui oleh orang tua.

6. Mobilitas sosial dan geografis. Bila keluarganya mengalami penaikan atau penurunan status sosial, atau pindah ke lingkungan yang baru, maka anak terpaksa akan mencari teman baru.

Pergantian teman merupakan pengalaman belajar yang berharga bagi seorang anak dan memainkan peranan penting dalam proses sosialisasi. Melalui pergantian pertemanan ini, anak akan mempelajari empat hal penting, yakni (Elizabeth B. Hurlock, 1978): 
1. Anak akan mempelajari sejauh mana makna akan pentingnya teman bagi anak-anak. hal tersebut akan memotivasi anak-anak untuk belajar menampilkan perilaku tertentu yang akan mencegah terjadinya pergantian teman di masa mendatang.

2. Anak akan mempelajari jenis teman apa yang tidak dapat memenuhi kebutuhan mereka akan teman, sehingga anak-anak mampu memusatkan diri pada teman yang dapat memenuhi kebutuhannya.

3. Bila anak mengetahu jenis anak yang tidak dapat memenuhi kebutuhannya akan teman, mereka akan menjadi lebih selektif, dan akan menguji calon teman bermain dan sahabat sebelum menjalin hubungan erat dengan mereka.

4. Anak akan belajar bahwa teman bermain dan sahabatnya akan memutuskan hubungan bila dia memperlakukan mereka secara anti sosial atau bila perilakunya tidak sesuai dengan nilai kelompok. Hal tersebut akan memotivasi untuk menyesuaikan diri terhadap harapan sosial, selain itu juga akan mendorong anak untuk mengutamakan minat dan aktivitas kelompok sehingga menjadi sosial dan tidak egosentris.

\section{Relasi Teman Sebaya}

Menjalin relasi atau hubungan dengan teman sebaya, merupakan salah satu contoh dari perkembangan sosial yang dimiliki oleh anak-anak pada usia sekolah dasar. Pada anak usia sekolah dasar, relasi atau menjalin hubungan dengan teman sebaya menjadi hal penting dalam perkembangan anak usia sekolah dasar. Berteman serta bersosialisasi dengan teman sebaya memberikan kontribusi bagi anak untuk bisa memahami dirinya dan juga memahami orang lain. Pada perkembangan ini, jika dibandingkan dengan anak usia dasar (preschoolers), anak usia sekolah dasar lebih bisa menyelesaikan masalah secara lebih efektif, bisa membujuk dan lebih bisa berkompromi dengan orang lain. Pada masa ini, anak-anak juga mulai bisa berbagi, dan membantu orang lain (Laura E Berk, 2006).

Hartub, dkk menuliskan bahwa hubungan sosial anak-anak dan remaja berpusat pada teman, sebagaimana juga berhubungan dengan keluarganya. Hal tersebut dikarenakan, pada usia sekolah dasar teman 
sebaya memiliki fungsi yang hampir sama dengan orang tua. Teman bisa memberikan ketenangan bila sedang mengalami kekhawatiran, dan tidak jarang pula anak yang awalnya penakut menjadi lebih berani karena pengaruh temannya.

Seperti halnya dengan masa awal anak-anak, berinteraksi dengan teman sebaya merupakan aktivitas yang banyak menyita waktu anak selama masa pertengahan dan akhir anak-anak. Barker dan Wright menyatakan bahwa untuk anak usia 2 tahun menghabiskan $10 \%$ dari waktu siangnya untuk berinteraksi dengan teman sebayanya. Pada usia 4 tahun, waktu yang digunakan untuk berinteraksi meningkat menjadi 20\%. Sedangkan untuk anak usia 7 sampai 11 tahun (middle childhood) meluangkan waktu lebih dari $40 \%$ waktunya untuk berinteraksi dengan teman sebayanya (Desmita, 2016).

Sementara itu, jumlah teman yang harus dimiliki oleh seorang anak untuk memuaskan kebutuhan mereka terhadap teman bervarisi menurut usia dan tingkat perkembangan mereka. Biasanya, jumlah teman yang dibutuhkan akan meningkat bila anak bertambah dewasa. Jumlah teman tersebut juga didasarkan tentang kepribadian dari anak tersebut, jika anak tersebut ekstrovert dan suka menjalin hubungan dengan orang lain, maka ia membutuhkan banyak teman, berbeda dengan jika anak tersebut introvert, maka ia akan kurang tertarik dengan kehidupan sosial, yakni berteman dengan orang lain. Selain itu, jumlah teman juga didasarkan atas minat bermain dari anak. Jika permainan yang berat, maka ia akan membutuhkan teman yang banyak dibandingkan dengan permainan biasa yang tidak membutuhkan banyak teman (Elizabeth B. Hurlock, 1978).

\section{Pengaruh Positif dan Negatif Relasi Teman Sebaya}

Ketika anak sudah memiliki menjalin suatu relasi dengan teman sebayanya, sudah pasti akan memiliki pengaruh-pengaruh, baik itu pengaruh positif maupun pengaruh negatifnya. Pada masa anak usia sekolah dasar (middle childhood), anak mulai menjauh dari pengaruh orang tua, sehingga kelompok atau teman sebaya membuka pandangan baru dan mulai membebaskan anak-anak untuk memberikan penilaian secara independen (penilaian bebas). Pada masa itu juga anak sudah 
menerima beberapa nilai, baik dari orang tua, guru, maupun dari teman sebayanya.

Beberapa pengaruh positif ketika anak usia sekolah dasar menjalin relasi teman sebaya, adalah (Diane E. Papalia,, 2008):

1. Anak-anak usia sekolah dasar akan mampu memutuskan nilai-nilai yang harus dipegang atau dilepas, ketika ia mengujikan nilai yang mereka terima dengan nilai yang dimiliki oleh teman sebaya.

2. Ketika anak-anak mulai menjalin relasi teman sebaya, mereka akan mulai membandingkan diri mereka dengan teman sebayanya, dengan demikian ia akan mampu menilai kemampuan yang mereka miliki secara realistis dan mendapatkan perasaan yang lebih jernih tentang kecakapan diri.

3. Dengan membentuk kelompok teman sebaya, maka anak-anak akan belajar tentang cara hidup bersama di lingkungan masyarakat

4. Anak-anak bisa mengerti terkait cara menyesuaikan keinginan dan hasrat mereka dengan keinginan teman sebayanya, dan mengerti kapan ia harus berteriak dan kapan harus diam.

Selain memiliki pengaruh positif, menjalin relasi dengan teman sebaya juga memiliki pengaruh yang negatif bagi anak-anak. Beberapa pemgaruh negatif ketika menjalin relasi dengan teman sebaya, yaitu (Diane E. Papalia,, 2008):

1. Ketika anak-anak berteman dengan teman yang teman sebaya yang memiliki sikap negatif, seperti pengutil (mengambil barang milik orang lain), menggunakan obat terlarang, dan bertingkah antisosial lainnya, maka anak akan cenderung meniru perilaku tersebut, karena anak pada usia sekolah dasar akan lebih cenderung meniru, dan jika bergaul dengan yang negatif, maka bisa mengubah anak menjadi seorang kriminal.

2. Kecenderungan anak menguatkan prasangka (prejudice), yakni sikap memusuhi orang luar, khususnya yang memiliki etnis atau ras yang lain.

Ketika anak-anak mulai bergaul dengan anak lain yang memiliki sikap anti sosial, sebagai orang tua, harus pandai mengontrol anaknya berteman dengan teman yang seperti apa, dan pandai memberikan 
pengertian yang lebih mengenai pengaruh buruk dari sikap antisosial tersebut, agar anak-anak bisa mengerti ia harus bergaul dengan teman sebaya yang tidak memiliki sikap anti sosial. Adapun ketika anak mulai melakukan prasangka kepada anak yang memiliki etnis atau ras lain, salah satu cara untuk mengurangi sikap tersebut adalah dengan memperluas pengalaman anak, bisa dengan diajarkan tentang suku atau ras lain. Selain itu, program yang paling efektif adalah dengan mengumpulkan anak dari berbagai kelompok yang berbeda untuk bekerja sama mencapai satu tujuan (Diane E. Papalia,, 2008).

\section{PEMBAHASAN}

\section{Relasi Anak Usia Sekolah Dasar Dalam Kelompok Teman Sebaya}

Pada masa anak usia sekolah dasar, mereka akan lebih sering menunjukkan untuk selalu bergabung dengan kelompoknya, dan lebih sering berinteraksi di dalam kelompok. Oleh karena itulah, pada masa ini sering disebut "usia kelompok". Anak usia sekolah dasar, seringkali akan merasa tidak puas bermain sendiri di rumah, atau melakukan kegiatan-kegiatan dengan keluarganya. Hal tersebut dikarenakan anak memiliki keinginan yang kuat untuk diterima sebagai anggota kelompok, serta merasa tidak puas bila tidak bersama teman-temannya. Dengan membuat suatu kelompok teman sebaya, nantinya anak-anak akan belajar berbagai ketrampilan sosial, seperti kepemimpinan, kesetiaan, dan kerja sama dengan orang lain.

Kelompok tersebut terbentuk secara alamiah di antara anak-anak yang hidup berdekatan atau yang pergi bersama ke sekolah. Kelompok tersebut bisa didasarkan karena berada di kelas yang sama, dan memiliki kesamaan jenis kelamin, etnis, dan popularitas. Anak-anak dari jenis kelamin yang sama memiliki ketertarikan yang sama, anak perempuan biasanya lebih dewasa dibandingkan anak laki-laki, dan anak laki-laki akan berbicara dan bermain dengan anak perempuan, dan sebaliknya. Kelompok dengan jenis kelamin yang sama akan membantu anak-anak untuk belajar perilaku sesuai dengan gendernya dan memasukkan peran gender ke dalam konsep diri mereka (Diane E. Papalia,, 2008). Selain itu, dalam menentukan suatu kelompok, anak usia sekolah dasar lebih menekankan pada aktivitas bersama-sama, tinggal di lingkungan yang 
sama, bersekolah di sekolah yang sama, serta berpartisipasi dalam organisasi masyarakat yang sama. Ketika anak-anak mulai berpartisipasi dengan organisasi masyarakatnya, maka ia mendapatkan ketrampilan sosial dan memiliki kematangan moral (Laura E Berk, 2006).

Sebagai orang tua juga terlibat untuk mengecek selalu kelompok teman sebaya anak-anak, agar terhindar dari perilaku yang negatif. Terdapat perubahan sifat dari kelompok teman sebaya pada anak usia sekolah dasar. Perubahan tersebut, yaitu:

1. Usia 6 sampai 7 tahun, kelompok teman sebaya tidak lebih kepada kelompok bermain, mereka memiliki sedikit peraturan dan tidak terstruktur untuk menjelaskan peran dan kemudahan berinteraksi di antara anggota-anggotanya.

2. Usia 9 tahun, kelompok-kelompok menjadi lebih formal. Pada usia ini, anak-anak akan berkumpul sesuai dengan minat yang sama dan mulai merencanakan perlombaan-perlombaan. Mereka membentuk suatu perkumpulan dengan aturan-aturan tertentu, kelompok ini memiliki keanggotaan inti, masing-masing anggota harus berpartisipasi dalam aktivitas kelompok, dan yang bukan anggota dikeluarkan.

3. Usia 10 sampai 12 tahun, anak-anak akan memilih teman bermain dari kelompok ras mereka sendiri, mereka masih menggunakan status sosial ekonomi sebagai bahan pertimbangan. Anak laki-laki dan anak perempuan memilih diantara teman bermainnya teman yang paling menyenangkan bagi mereka dan yang dengannya mereka tidak hanya dapat bermain tetapi juga dapat berkomunikasi dengan baik (Elizabeth B. Hurlock, 1978).

Karakteristik lain dari pola relasi anak usia sekolah dasar dengan teman sebayanya adalah munculnya keinginan untuk menjalin hubungan pertemanan yang lebih akrab atau dalam kajian psikologi perkembangan dikenal dengan istilah friendship (persahabatan). Seperti persahabatan pada masa dewasa, persahabatan pada masa anak-anak usia sekolah dasar juga diwarnai karena adanya persamaan. Sepanjang masa anakanak, sahabat lebih banyak memiliki persamaan daripada perbedaan dilihat dari beberapa faktor, yakni usia, jenis kelamin, suku, satu 
sekolah, dan sebagainya. Sahabat seringkali memiliki sikap yang sama terhadap sekolah, aspirasi yang sama terhadap pendidikan, serta orientasi prestasi yang sejalan. Sahabat dapat diartikan sebagai orang yang dengannya anak tidak hanya dapat bermain, tetapi juga berkomunikasi melalui pertukaran ide dan rasa percaya, permintaan nasihat, dan kritik (Benedictine Wisdyasinta, 2012).

Menurut santrock, karakteristik yang paling umum dari persahabatan adalah keakraban dan kesamaan. Keakraban dapat diartikan sebagai penyingkapan diri dan berbagai pemikiran pribadi. Keakraban ini menjadi dasar bagi relasi anak dengan seorang sahabat. Karena kedekatan inilah, anak mau menghabiskan banyak waktunya dengan sahabat dan mengekspresikan efek yang lebih positif terhadap sahabat dibandingkan dengan yang bukan sahabatnya., dan bersedia mengungkapkan dirinya secara terbuka. Selain itu, anak juga lebih bersedia berbagi dengan sahabat, meskipun sering terjadi situasi persaingan, sehingga menurunkan kesediaan mereka untuk berbagi dengan sahabat (Desmita, 2016).

Persahabatan pada anak usia sekolah dasar menjadi lebih kompleks dibandingkan dengan anak usia dasar. Seorang sahabat, ia adalah seorang yang disayangi oleh seorang anak, yang membuatnya merasa nyaman, rela melakukan berbagai hal bersama, dan yang dapat dibagi rahasia dan perasaan. Dalam menjalin suatu persahabatan, seorang anak akan lebih mengutamakan kepercayaan, ia juga akan mengetahui sahabatnya, merasakan keterikatan kepada yang lain, dan memberlakukan yang lain sederajat (tidak membeda-membedakan). Persahabatan yang paling kuat meliputi komitmen yang sama dan give and take. Bahkan anak yang kurang populer dapat menciptakan persahabatan, hanya saja sahabat mereka lebih sedikit dibandingkan anak yang populer dan cenderung akan menemukan sahabat diantara anak yang berusia yang lebih muda, anak tidak populer lainnya, atau anak di kelas atau sekolah yang berbeda (Diane E. Papalia , 2008).

Willard Hartup, menjelaskan bahwa sahabat dapat menjadi sumber daya kognitif dan emosi dari masa anak-anak hingga tua, sahabat juga dapat meningkatkan penghargaan diri dan rasa sejahtera. 
Persahabatan itu sendiri memiliki enam fungsi, yaitu (Benedictine Wisdyasinta, 2012):

1. Pertemanan (Companionship). Dengan bersahabat akan memungkinkan anak-anak memiliki seorang rekan dan pasangan untuk bermain, seorang yang bersedia meluangkan waktu bersama mereka dan bergabung dalam aktivitas kerja sama.

2. Stimulasi atau pendorong (Stimulation). Persahabatan memungkinkan anak-anak memperoleh informasi yang menarik, kegembiraan, hiburan, menggairahkan, dan mengasyikkan.

3. Dukungan fisik (Physical support). Seorang sahabat akan memberikan waktu, sumber daya, pertolongan, dan kemampuankemampuan.

4. Dukungan ego (Ego Support). Sahabat akan memberikan dukungan, pengukuhan, dan umpan balik, yang dapat membantu anak-anak membina kesan atas dirinya sebagai individu yang mampu, menarik, dan berharga.

5. Perbandingan sosial (Social comparison). Persahabatan memungkinkan anak-anak memperoleh informasi mengenai posisinya diantara anak-anak lain dan apakah ia baik-baik saja.

6. Sebagai pemberi keakraban dan perhatian (Affection and intimacy). Persahabatan memungkinkan anak-anak untuk menjalin hubungan dengan orang lain secara hangat, dekat, dan percaya. Keakraban dalam persahabatan memiliki ciri adanya keterbukaan diri (selfdisclosure) dan berbagi terkait pikiran-pikiran pribadi. Riset mengatakan bahwa persahabatan yang akrab, bisa jadi tidak muncul hingga awal dewasa.

Selain keenam fungsi tersebut, persahabatan juga memiliki peranan yang sangat penting dalam perkembangan psikososial anak usia sekolah dasar, diantaranya (Desmita, 2016):

1. Dengan bersahabat maka akan mengajarkan kepada anak untuk mempelajari berbagai ketrampilan terntentu. Seperti cara berkomunikasi yang baik satu sama lain, anak bisa memperoleh pengalaman belajar untuk mengenali kebutuhan dan minat orang lain, 
serta mengetahui cara bekerja sana dan mengelola konflik bersamasama.

2. Persahabatan memungkinkan anak untuk membandingkan dirinya dengan individu lain, karena seorang anak akan menilai dirinya berdasarkan perbandingan dengan sahabatnya.

3. Persahabatan akan mendorong munculnya rasa memiliki terhadap kelompok. Pada usia 10-11 tahun, kelompok akan menjadi penting. Anak akan menemukan sebuah organisasi sosial yang tidak hanya terdiri atas sekumpulan individu, melainkan juga mencakup adanya suatu peran tertentu, partisipasi kolektif, dan dukungan kelompok untuk melakukan aktivitas-aktivitas kelompok.

Konsep persahabatan yang dimiliki oleh seorang anak dan cara mereka bertingkah laku terhadap suatu teman, akan berubah seiring dengan usia. Persahabatan antara anak sekolah lebih dalam dan lebih stabil. Anak-anak tidak dapat menjadi, atau mendapatkan teman dalam arti yang sebenarnya sampai mereka mencapai kematangan kognitif untuk dapat memperhitungkan dan mempertimbangkan pandangan dan kebutuhan orang lain di samping pandangan dan kebutuhannya sendiri. Robert Selman menemukan adanya perubahan konsepsi persahabatan dalam lima tahap yang saling tumpang tindih. Dia menemukan bahwa sebagian besar anak usia sekolah dasar berada di tahap 2 (persahabatan yang berdasarkan ketertarikan pribadi). Kelima tahap tersebut adalah (Diane E. Papalia, 2008):

\begin{tabular}{|c|c|c|}
\hline Tahap & Deskripsi & Contoh \\
\hline $\begin{array}{l}\text { Tahap 0: } \\
\text { bermain } \\
\text { tahun) }\end{array}$ & $\begin{array}{l}\text { Disebut level tak berpilah, } \\
\text { anak-anak memiliki sifat } \\
\text { egosentrik dan kesulitan } \\
\text { mempertimbangkan sudut } \\
\text { pandang orang lain, yakni } \\
\text { hanya memikirjan apa yang } \\
\text { mereka inginkan dari suatu } \\
\text { hubungan. } \\
\text { mendefinisikan pertemanan } \\
\text { mereka dengan kedekatan } \\
\text { fisik dn menilai berdasarkan } \\
\text { atribut materi atau fisik }\end{array}$ & 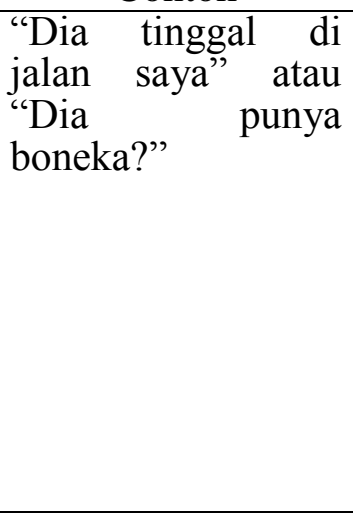 \\
\hline $\begin{array}{l}\text { Tahap 1: Bantuan } \\
\text { satu arah (usia 4- }\end{array}$ & $\begin{array}{lrr}\text { Disebut } & \text { dengan } & \text { level } \\
\text { unilateral, } & \text { yakni } & \text { yang }\end{array}$ & $\begin{array}{l}\text { "Dia bukan teman } \\
\text { saya lagi karena }\end{array}$ \\
\hline
\end{tabular}




\begin{tabular}{|c|c|c|}
\hline 9 tahun) & $\begin{array}{l}\text { dimaksud dengan teman baik } \\
\text { adalah yang melakukan apa } \\
\text { yang dikehendaki oleh } \\
\text { temannya. }\end{array}$ & $\begin{array}{l}\text { tidak mau pergi } \\
\text { bersama ketika } \\
\text { saya mengajaknya" } \\
\text { atau "Dia teman } \\
\text { saya karena selalu } \\
\text { mengiyakan ketika } \\
\text { tiap kali saya } \\
\text { meminjam } \\
\text { penghapusnya) }\end{array}$ \\
\hline $\begin{array}{l}\text { Tahap 2: Kerja } \\
\text { sama } \\
\text { penyelesaian adil } \\
\text { dua arah (usia 6- } \\
12 \text { tahun) }\end{array}$ & $\begin{array}{l}\text { Disebut level resiprokal, } \\
\text { level ini melengkapi tahap } \\
\text { pertama. Tahap ini meliputi } \\
\text { memberi dan menerima tetapi } \\
\text { masih melayani berbagai } \\
\text { kepentingan terpisah daripada } \\
\text { kepentingan bersama dua } \\
\text { orang teman. }\end{array}$ & $\begin{array}{l}\text { "Kami berteman } \\
\text { dan kami saling } \\
\text { melakukan sesuatu } \\
\text { untuk yang lain" } \\
\text { atau "Seorang } \\
\text { teman adalah yang } \\
\text { bermain bersama } \\
\text { anda ketika tidak } \\
\text { ada orang lain yang } \\
\text { mau bermain } \\
\text { dengan anda" }\end{array}$ \\
\hline $\begin{array}{l}\text { Tahap } \quad 3: \\
\text { Hubungan yang } \\
\text { intim dan berbagi } \\
\text { secara mutual } \\
\text { (usia 9-15 tahun) }\end{array}$ & $\begin{array}{l}\text { Disebut level mutual, yakni } \\
\text { melihat persahabatan } \\
\text { memiliki kehidupannya } \\
\text { sendiri. Hal ini merupakan } \\
\text { hubungan } \\
\text { berkesinambungan, sistemati, } \\
\text { dan penuh dengan komitmen, } \\
\text { teman menjadi posesif, dan } \\
\text { menuntut ekslusivitas. }\end{array}$ & $\begin{array}{l}\text { "Dibutuhkan waktu } \\
\text { yang lama untuk } \\
\text { membuat sahabat } \\
\text { yang dekat, karena } \\
\text { itu akan merasa } \\
\text { sangat buruk } \\
\text { apabila teman kita } \\
\text { mencoba membuat } \\
\text { pertemanan } \\
\text { lainnya" }\end{array}$ \\
\hline $\begin{array}{l}\text { Tahap 4: } \\
\text { Interdependen } \\
\text { otonomus (mulai } \\
\text { usia 12 tahun) }\end{array}$ & $\begin{array}{l}\text { Pada tahap ini, anak akan } \\
\text { mulai menghormati keinginan } \\
\text { yang lain terhadap } \\
\text { ketergantungan dan otonomi. }\end{array}$ & $\begin{array}{l}\text { "Seorang teman } \\
\text { yang baik adalah } \\
\text { komitmen yang } \\
\text { nyata, sebuah } \\
\text { resiko yang harus } \\
\text { diambil, harus bisa } \\
\text { mendukung, } \\
\text { memercayainya, } \\
\text { dan memberi, akan } \\
\text { tetapi, ia juga harus } \\
\text { mampu } \\
\text { membiarkannya } \\
\text { pergi." }\end{array}$ \\
\hline
\end{tabular}

Tabel 2.1 Tahap Pertemanan Selman

Selain Selman, Hetherington dan Parke juga menggambarkan tiga tahap perkembangan gagasan anak tentang persahabatan, ketiga tahap tersebut adalah (Desmita, 2016): 
1. Reward-cost stage (7-8 tahun). Pada tahap ini anak menyebutkan ciriciri sahabat sebagai teman yang menawarkan bantuan, melakukan kegiatan bersama-sama, bisa memberikan ide-ide, bisa bergabung dalam permainan, menawarkan judgement, dekat secara fisik.

2. Normative stage (10-11 tahun), anak akan mengharapkan sahabatnya bisa menerima dan mengagumi dirinya, setia, dan memberikan komitmen dengan persahabatan, serta mengekspresikan nilai dan sikap yang sama terhadap aturan-aturan dan sanksi.

3. Emphatic stage (11-13 tahun), anak mengharapkan kesungguhan dan potensi keakraban dari seorang sahabat, mengharapkan sahabat untuk memahami dirinya, mau menerima pertolongannya, berbagai minat dan mempertahankan sikap dan nilai yang sama.

\section{Penyesuaian Sosial dan Penerimaan Teman Sebaya (Sosial) pada Anak Usia Dasar}

Penyesuaian diri diartikan sebagai keberhasilan seseorang untuk menyesuaikan diri terhadap orang lain pada umumnya dan pada kelompoknya pada khususnya. Orang yang dapat menyesuaikan diri dengan baik maka ia akan mempelajari berbagai ketrampilan sosial seperti kemampuan untuk menjalin suatu hubungan dengan orang lain, baik teman maupun orang yang tidak dikenal, sehingga sikap orang lain terhadap mereka menyenangkan. Anak-anak diharapkan agar semakin lama dapat semakin menyesuaikan diri dan dapat memenuhi harapan sosial sesuai dengan usia mereka.

Melakukan penyesuaian sosial yang baik bukanlah hal yang mudah, sebagai akibatnya banyak anak yang masih belum bisa menyesuaikan diri ketika menjalin suatu hubungan atau relasi dengan teman yang sebayanya. Terdapat banyak kondisi yang bisa menimbulkan kesulitan bagi anak untuk menyesuaikan diri mereka dengan baik, yaitu (Elizabeth B. Hurlock, 1978):

1. Jika perilaku sosial yang buruk dikembangkan di lingkungan rumah, maka anak akan kesulitan untuk melakukan penyesuaian sosial yang baik di luar rumah. Misalnya, anak yang serba dibolehkan di rumah, maka ia akan menjadi anak yang tidak mau memperhatikan keinginan orang lain, merasa bahwa ia mampu mengatur dirinya sendiri. 
2. Jika di rumah kurang diberi model perilaku untuk dapat ditiru, maka anak akan memiliki kesulitan juga dalam menyesuaikan diri. Anak yang meniru perilaku orang tuanya yang menyimpang, maka ia akan mengembangkan kepribadian yang tidak stabil, agresif, mendorong mereka untuk melakukan tindakan yang penuh dendam, ketika mereka mulai dewasa.

3. Kurangnya motivasi untuk belajar menyesuaikan diri di sosialnya ataupun dengan temannya. Misalnya, ketika di rumah diperlakukan sebagai anak yang tidak dikehendaki dalam suatu permainan, maka tidak akan memiliki motivasi yang kuat untuk berusaha melakukan penyesuaian yang baik.

4. Jika tidak memiliki bimbingan dan bantuan yang cukup dalam proses belajar menyesuaikan diri di sosialnya, maka ia juga akan mengalami kesulitan penyesuaian sosialnya.

\section{SIMPULAN}

Pada anak usia sekolah dasar, berteman serta bersosialisasi dengan teman sebaya memberikan kontribusi bagi anak untuk bisa memahami dirinya dan juga memahami orang lain. Pada perkembangan ini, jika dibandingkan dengan anak usia dasar (preschoolers), anak usia sekolah dasar lebih bisa menyelesaikan masalah secara lebih efektif, bisa membujuk dan lebih bisa berkompromi dengan orang lain. Pada masa ini, anak-anak juga mulai bisa berbagi, dan membantu orang lain

Ketika anak sudah memiliki menjalin suatu relasi dengan teman sebayanya, sudah pasti akan memiliki pengaruh-pengaruh, baik itu pengaruh positif maupun pengaruh negatifnya. Pada masa anak usia sekolah dasar, mereka akan lebih sering menunjukkan untuk selalu bergabung dengan kelompoknya, dan lebih sering berinteraksi di dalam kelompok. Oleh karena itulah, pada masa ini sering disebut "usia kelompok". Sepanjang masa anak-anak, sahabat lebih banyak memiliki persamaan daripada perbedaan dilihat dari beberapa faktor, yakni usia, jenis kelamin, suku, satu sekolah, dan sebagainya.

Penyesuaian diri diartikan sebagai keberhasilan seseorang untuk menyesuaikan diri terhadap orang lain pada umumnya dan pada kelompoknya pada khususnya. Anak-anak diharapkan agar semakin 
lama dapat semakin menyesuaikan diri dan dapat memenuhi harapan sosial sesuai dengan usia mereka. Penerimaan sosial berarti ia dipilih sebagai teman untuk suatu aktivitas dalam kelompok di mana seseorang menjadi anggota. Ini merupakan indeks keberhasilan bagi seorang anak yang digunakan untuk berperan dalam suatu kelompok sosial dan menunjukkan derajat rasa suka anggota kelompok yang lain untuk dapat bekerja atau bermain dengannya.

\section{DAFTAR PUSTAKA}

Berk, E Laura. 2006. Development Through the Lifespan. America, United States of America.

Desmita. 2016. Psikologi Perkembangan Peserta Didik, Bandung, Remaja Rosdakarya.

Hurlock, B. Elizabeth. 1978. Perkembangan Anak Jilid 1, Jakarta, Penerbit Erlangga.

Wisdyasinta, Benedictine (penj). 2012. Perkembangan Masa-Hidup, Jakarta, Penerbit Erlangga.

Papalia, E. Diane. 2008. Human Development (Psikologi Perkembangan), Jakarta, Kencana Prenada Media Group.

Cook dan SammelCook, B. G., \& Semmel, M. I. 1999. Peer acceptance of included students with disabilities as a function of severity of disability and classroomcomposition. The Journal of Special Education, 33(1), 50-61. doi: 10.1177/002246699903300105.

Bricker, D. 2000. Inclusion: How the scene has changed. Topics in Early Childhood Special Education, 20, 14-19. Doi: $10.1177 / 027112140002000103$. 